Allan O. Pfnister

\title{
Historical Perspective and Current Issues in the Preparation of College Teachers
}

$T$

HAT the most striking feature of the contemporary American higher educational "system" is its great diversity is hardly debatable; the evidence is everywhere about us. Included in the system are tiny single-purpose colleges with a few hundred students and massive universities with a dozen professional schools and thousands of students-and all of the variations in between.

Differences are not simply in the size of enrollments; institutions of higher education exhibit striking variations in curriculum, type of student body, orientation of the faculty and administration, and countless other facets of the operation. Yet the preparation of staff members for these institutions falls under the single general heading of "preparation of college teachers." With such diversity among institutions it is perhaps not too surprising that there are such different conceptions of the role of and the best kind of preparation for college teaching.

\section{Early Developments}

By way of contrast, the American college of the eighteenth and nineteenth centuries was a relatively simple enterprise. Although it was organized to prepare students generally for professional life, the college saw its task as only that of laying the foundations, or in the words of the Yale Report of 1828, of providing the "discipline and the furniture of the mind."
This it proceeded to do by grouping the students into classes and sending them through a rather fixed curriculum. One teacher or tutor customarily took a single class through all of the subjects for the year. Instruction was largely by recitation, although lecturing grew in significance during the latter part of the nineteenth century.

To teach in such a program did not require specialized training. The typical faculty member was a general scholar with a baccalaureate degree and, most likely, some theological training. The student could not assume that the professor was much beyond himself in scholarship and training. In spite of the occasional Mark Hopkins, the picture of college teaching appears to have been rather dismal. Andrew D. White, first president of Cornell University, gives the following description:

The professors, though frequently men of high character and ability, were few and poorly paid. . . . Money was also saved by requiring one professor to teach many different subjects, his instruction being considered satisfactory if by diligent reading he could keep just ahead of his students. Much money was saved, too, by the employment of tutors.... They were as a rule young men just out of college, "very poor and very pious," who while studying in the adjacent

Dr. Pfnister is associate professor of higher education, the University of Michigan, Ann Arbor. 
theological school would, for a small stipend, sit in a box three times a day and "hear recitations." This, as a rule, meant hearing young men give the words of a textbook as nearly as possible, or construe Latin or Greek mainly from the inevitable surreptitious translation, the tutor rarely discussing the subject or making the slightest comment on it, but simply making a mark on his private book to denote his view of the goodness or badness of each performance. 1

During the early nineteenth century there were some attempts to provide more adequate preparation for college teachers. The impetus came from a few young teachers such as Benjamin Silliman, Edward Everett, and George Ticknor, who had the advantage of studying abroad. They returned with the hope of introducing to the American colleges some of the features of the German university.

When George Ticknor was appointed in 1819 to the Smith Professorship of French and Spanish Languages and Literature he demanded sufficient time to prepare as good lectures as his talents and industry would permit. He wanted the students to have an opportunity to hear him and he did not want to be obliged to drill them on the elements of language. As a member of the Harvard faculty, he argued for rather extensive changes in the whole curriculum, but faculty opposition and the financial exigencies of the college effectively halted his efforts.

\section{Instruction for College Teachers}

A few years later what was perhaps one of the first attempts to organize a formal training program for college teachers in America was started at Harvard. Charles Beck, a German classicist with a Tübingen doctorate convinced President Josiah Quincy that a philological semi-

\footnotetext{
1 Andrew D. White, "The Need for Another University," Forum 6:466; January 1889.
}

nary of the German type ought to be established at Harvard.

At that time, the typical German seminary, as it was called, consisted of a small group of students admitted to membership on the basis of an examination "in any Greek author, held in the Latin tongue by the principals of the seminary." 2 The students were required "to attend the daily exercises and to interpret and to dispute, in their turn, under the direction of one of the professors."3

Another feature of the seminary was the writing during every term of one or two dissertations. Graduates of the seminaries were sought after as instructors in the gymnasia, and many of them remained at the university as private teachers. Beck thought that a complete seminary at Harvard might consist of a department of classical philology, a department of history, and a department of mathematics. The presence of such a program, he argued, would enable Harvard to become a true university.

The Harvard Corporation voted in August, 1831, to establish a department to teach the theory and practice of instruction, with Beck as the principal instructor. The program continued for a few years, but the lack of fellowships for students as well as general financial problems again facing Harvard brought the program to an early end.

\section{Growth of Specialization}

As the nineteenth century wore on, American colleges were being called upon increasingly to meet the challenges of the growth of knowledge and the demands for specialized education. In 1847 a committee at Yale recommended the

\footnotetext{
2 B. John Russell, "A Tour in Germany, and Some of the Southern Provinces of the Austrian Empire, in the Years $1820,1821,1822, "$ reprinted from the second Edinburgh edition, Boston, 1825, North American Review 27:336; October 1828.

Ibid.
} 
establishment of a Department of Philosophy and Arts open to graduates of Yale and other colleges. The reasoning of the committee was that from time to time new branches of study were called for by the public. If these were put into the undergraduate curriculum, they would crowd and interfere with the undergraduate courses. If, however, the new courses could be offered in distinct departments, this could be avoided.

Thirteen years later, in 1860, the faculty proposed and the Corporation agreed to let the College offer the Ph.D. degree for high attainment in mathematics, philology, or any other branches that might be taught in the Department of Philosophy and Arts. The first doctorate was conferred in 1861 .

The emergence of advanced programs, typified by the early doctoral study at Yale, set in motion a whole new combination of conditions. Clearly, the "poor and pious" tutor was no longer qualified to carry on the kind of instruction demanded. Advanced courses demanded teachers with advanced training.

The establishment of parallel courses of study at Cornell, the opening of Johns Hopkins in 1876 as a true university, followed by Clark in 1888 and Chicago in 1892, emphasized even more forcibly the need for faculties with greater and more specialized training. The emphasis shifted to research, and at Chicago President Harper announced that promotions would be based on scholarly productivity.

As the university concept grew, specialization became an integral part of the academic world. The branches of knowledge were divided and sub-divided. Whereas there were relatively few persons engaged in teaching single subjects during and up to the end of the nineteenth century, by the beginning of the twentieth century the general college teacher had been transformed into a specialist in history, linguistics, mathematics, or some other field of knowledge.
The image of the college professor was definitely undergoing change and college teaching was being transformed into a profession; at the same time the kind of emphasis necessary in the development of the university was setting the stage for the next half-century of debates over the relative importance of research and teaching. As the college teacher became a professional, he became a specialist. As a specialist, however, he increasingly turned his attention to research and to the training of more researchers. The distinction between undergraduate and graduate education became blurred, and graduate education, because it was advanced, began to set the tone for undergraduate education as well.

\section{The Doctorate}

The doctorate came to be accepted as the basic degree for the college teacher. Although the accrediting agencies have been blamed for the overweening emphasis on the doctorate, Berelson correctly points out that the decision that the doctorate should be the standard degree for college faculty members was concluded long before the accrediting agencies came into the picture. ${ }^{4}$

Attempts were made in the early years of the twentieth century to emphasize the master's degree or a special two-year master's degree for college teachers, but the doctorate emerged as the degree. As early as 1903, William James was writing about "the Ph.D. octopus." Among other things, he said:

... is not our growing tendency to appoint no instructors who are not also doctors an instance of pure sham? Will anyone pretend for a moment that the doctor's degree is a guarantee that its possessor will be successful as a college teacher. . . ? The truth is that the Doctor-Monopoly in teaching, which is becoming so rooted in Amer-

\footnotetext{
- Bernard Berelson, Graduate Education in the United States (New York: McGraw-Hill, 1960) p. 20, 21.
} 
ican custom, can show no serious grounds whatsoever for itself in reason. 5

James had some proposals for remedying the situation: the degree could be awarded after a given period of time as a matter of course, like the bachelor's degree; colleges and universities could cease insisting upon the doctorate as the mark of preparation for college teaching; and the students could simply bypass the degree when it appeared that it would interfere with their own independent study.

Despite the criticisms of James and others, the graduate schools grew in strength and in influence, and as advanced degrees became more and more the mark of academic respectability, the debates over the proper preparation for college teachers became more frequent and more bitter. The Ph.D. became the reward for advanced study at a time when the emphasis was upon original investigation, the expansion of knowledge, and the training of researchers. And yet there were some who were convinced that college teaching, as distinguished from university teaching, merited a different kind of preparation.

Throughout the 1920's and 1930's conference after conference dealt with the possibility of developing two doctoral degrees, one for researchers and one for teachers. It was argued that the typical Ph.D. program was too specialized, and that potential college teachers needed some direct training in teaching as well as in the discipline in which they were going to teach.

\section{The General Education Movement}

The emerging general education movement represented an attempt to recall an earlier period when more unity existed in the undergraduate curriculum.

5 William James, "The University and the Individual: The Ph.D. Octopus," Memories and Studies (New York: Longmans, Green, 1917) p. 337-38.
With the growing specialization and the multiplication of fields of knowledge, it was becoming abundantly clear that no undergraduate could expect to gain competence in all fields of study. The specialization characterizing the graduate schools was dipping into the undergraduate curriculum; students entered the undergraduate college with the intent to "major" in a particular discipline.

As the emphasis was placed more and more upon the undergraduate college providing the student with immediately marketable skills, the general education movement insisted that the student should receive a broad basic education during his undergraduate years. General education emphasized integrated knowledge and basic principles underlying the broader areas of knowledge. As new survey and integrated courses were developed, it became clear that such approaches could only be as successful as the faculty available to teach the courses. The general education movement thus added its voice to the demands for a reform in the preparation of persons who were to become college teachers.

\section{Current Problems}

Most of the current discussions about the preparation of college teachers seem to revolve around the proper purpose of graduate training and the relative emphasis upon research versus teaching. Graduate faculties insist that the proper function of the graduate school is to carry on research and to train others to engage in research. On the other hand, the colleges argue with equal vehemence that the proper function of graduate training is to prepare persons for positions on college faculties. When the issues are thus drawn so sharply, the chances for a meeting of the minds are relatively slight. In a sense, both positions are correct and both positions are in error.

If the review of the historical development above has any validity, it should be clear that the structure of the American 
college has changed in dramatic ways during the last sixty to seventy years. The simple curriculum and the simple procedures of the colonial college are a far cry from the organization and procedures of the modern American college and university. In a rapidly changing world, characterized by the development of new technologies and whole new areas of learning, the college could hardly have avoided becoming more specialized in its approach to the world of knowledge; the university with its departmentalization was an inevitable development.

On the other hand, the increasing departmentalization of knowledge has undoubtedly led to a fragmentary approach to the world. More and more specialization seems to lead to less and less communication between the fields of knowledge. The stronger the forces toward specialization and the weaker the forces toward a common knowledge, the greater the apparent need for some kind of general approach. Although man is a specialist, he is also an individual man and "therefore united with his fellowmen, past, present, and in the future... though certain responsibilities must be discharged by each individual out of his special competence, others could be discharged only in the exercise of a kind of understanding which all men should strive to possess." 6

In the light of the changed circumstances in higher education, what are some of the specific issues currently being raised concerning the preparation of college teachers? Let me suggest a few of the more pressing of these issues.

\section{The Teaching Process}

The first relates to the nature of the teaching process itself. Much of the discussion of the preparation of college teachers is doomed to frustrating incon-

\footnotetext{
- Russell Thomas, The Search for the Common Learning: General Education, $1800-1960$ (New York: McGraw-Hill, 1962) p. 62.
}

clusion because it lacks any common frame of reference. What is needed is a theoretical model-or a series of models -of teaching qua teaching. What are the essential elements in teaching? Which of these are amenable to some training program?

Without trying to provide a full-scale model, let me suggest one direction in which such a model might develop. If we view teaching as a social process, we find that we cannot treat of the teacher sui generis. The teacher does not stand alone; he must be considered in terms of what he does within what may be called the teaching situation.

In its simplest terms, the teaching situation would seem to reduce itself to the following elements: teacher, student, subject matter, communication. These elements stand in a set of complex relationships. We have the teacher in relation to subject matter, in relation to the student, and in communication with the student relative to subject matter.

Analyzing each of these relationships, we begin to develop a model of the teacher qua teacher. With respect to subject matter, for example, the teacher is not a phonograph, playing back bits of information gathered hither, thither, and yon. Rather, the teacher is personally responsible for having encountered the world of knowledge and having fashioned out of this encounter something called subject matter. Subject matter in the teaching situation is something personal. A teacher must, accordingly, be thoroughly grounded in the discipline with which he is dealing.

On the other hand, the possessor of subject matter may not be a teacher. For the teaching situation demands the student and the communication between teacher and student. The communication involves a give-and-take. When involved in communication, the teacher faces the whole question of methodology. Method of communication may vary with the personality of the teacher and with 
the nature of the subject matter itself. But essentially, methodology involves the best possible conversation between the teacher and the student. The conversation is not haphazard; it is initiated, carried forward to an end, and has purpose and direction.

If one then begins to analyze the various elements within the teaching-learning situation, he soon finds that the preparation of a teacher is a complex and long-term operation. The teacher must become so thoroughly immersed in his discipline that he participates creatively in developing the subject matter with which he deals in teaching. At the same time he must be able to relate the generalizations of his subject matter to other areas of experience, and he must be an effective communicator so that he may inspire the student also to begin to encounter in a direct way the data of experience from which the subject matter is formed.

Neither of these skills is wholly to be attained through a process of formal education in the graduate school. The graduate school assists the future college teacher to begin to develop skills in formulating subject matter-and this is more than simply engaging in research in order to complete a dissertation; the teacher must gain skill in formulating subject matter within the context of the teaching situation. Similarly, any formal training in communication can be viewed as only a beginning; it is something that must be carried on throughout one's teaching career.

\section{Teacher and Faculty Member}

A second issue involves the role of the teacher in relation to the role of the faculty member. While the two terms are regularly used interchangeably, "teacher" and "faculty member" are not synonomous. A teacher is one who engages in the process of teaching as described above. A faculty member is a person who is associated with the aca- demic staff of a college or university. Ordinarily, he is also engaged in teaching, the amount depending upon the size and type of the institution. Every college teacher is a faculty member, but not every faculty member is a teacher.

The faculty member has many roles: he is a member of one or more committees engaging in policy-making and/or administration; he is a counselor of students in matters academic and nonacademic; he is a researcher, to a greater or lesser degree; he deals with students at various levels of development; he must express himself before his peers. The role of the faculty member varies with the size, control, and complexity of his institution.

All of this is rather obvious, but because the distinction between faculty member and teacher is not always made, we find ourselves in many discussions about the preparation of college teachers that can end only in an impasse.

The single-purpose undergraduate college wants-or says it wants-a faculty member who will devote the greater part of his time to meeting students and working directly with them. The large and complex university engaged in research seeks a person who can devote a great deal of his time to independent work and writing; status is determined by the kind and amount of research he carries on and the nature of his publications.

The person caught up in the activities of the complex university finds it difficult to understand the peculiar needs of the undergraduate college. The undergraduate college, on the other hand, fails to understand the significance of research within the context of the university. Yet in both situations the function of teaching, as described in an earlier section above, is generically the same. Teacher and student in communication vis-à-vis subject matter constitute the same formal situation in the university as in the small, undergraduate college. The difference between the two is in the other roles that 
accrue and the degree of emphasis placed upon these various roles.

\section{Recruitment}

A third issue has to do with the way in which persons are attracted to college teaching. It seems clear that the projected increases in enrollment will place heavy demands upon the college and university teaching staffs. Whatever the precise number of new teachers required -and I am not going to try to reconcile the diverse projections-it seems clear that we shall have to become involved in a more systematic recruiting of college teachers.

The study of faculties in Minnesota by Drs. Eckert and Stecklein indicated that most college teachers only gradually find their way into the teaching profession. ${ }^{7}$ On the basis of their very careful study of 752 full-time faculty members in thirtytwo private and public colleges in the fall of 1956, they found that only 3 per cent began their undergraduate study with any idea of becoming college teachers.

By the time they had received their baccalaureate degrees, only 15 per cent had any intention of becoming college teachers, and even by the time that they had received their highest degree, collectively only 48 per cent had college teaching as their vocational goal.

By that time some 88 per cent had considered the possibility of entering college teaching, but most of them had no immediate intention of becoming college teachers. This is all by way of vivid contrast with the vocational orientation of future physicians who typically reach the decision regarding their future at the age of eighteen, after having already considered the possibility for several years.

\footnotetext{
${ }^{7}$ Cf. Ruth E. Eckert and John E. Stecklein, Job Motivations and Satisfactions of College Teachers, U.S. Department of Health, Education, and Welfare, Office of Education, Cooperative Research Monograph No. 7 (Washington, D.C.: Government Printing Office, 1961).
}

Gustad's study of college teachers in psychology, chemistry, and English indicates that:

... by and large, however, entry into teaching is the end product of drift. That is, the majority do not engage in the kind of career planning that is typical of the aspiring physician or attorney. 8

Martin Trow would modify the statement that college teachers find their way into teaching by a process of drift. He says the drift may be more apparent than real:

What appears to be drift, in the absence of early conscious decisions to go into college teaching, may actually be rather highly determined by specific early life experiences and by the broad social statuses that shape those experiences. There are some combinations of class, ethnic, and religious origins that are simply extremely unlikely to produce college teachers; there are other combinations which seem to be associated with recruitment to different fields of study and different kinds of institutions. ${ }^{9}$

Trow also argues that college teaching is not one profession, but that it is many and that:

... similarly, there is not one market for college teachers but many, defined in part by region, by type of institution, by discipline, and by many factors of image and reputation about which we know only too little.10

A study of the baccalaureate origins of college teachers suggests a close relationship between the type of institution in which the baccalaureate was received and

${ }^{8}$ John W. Gustad, The Career Decisions of College Teachers (Atlanta: Southern Regional Education Board, 1960) p. 6.

B Martin Trow, "Reflections on the Recruitment to College Teaching," Faculty Supply, Demand, and Recruitment (Proceedings of a Regional Conference Sponsored by the New England Board of Higher Education, November 5-7, 1959) p. 57.

${ }^{10}$ Ibid., p. 53. 
the institution in which the person later follows his teaching career.11 Although the various bits of evidence are fragmentary and not entirely clear, it does seem that a more active process of recruitment is necessary.

A series of programs recently initiated under grants from the Ford Foundation suggests one way in which this may be carried on. Designed to identify at an earlier stage potential college teachers, each of these programs seeks to work out a sequence of experiences, beginning with the junior year at the undergraduate institution and proceeding through at least the first year of graduate study, that will encourage students to think of college teaching as a career at an earlier date and that will both deepen and hasten preparation for teaching.

By and large, college faculty members are reluctant to encourage their students to enter college teaching; some institutions, however, send an inordinately large number of persons into college teaching. It does seem that it would be possible to communicate in a more positive manner the excitement and possibilities of college teaching-even at the undergraduate level.

\section{Teacher and Student}

A fourth issue has to do with the impact of the teacher upon the student. The well known and oft-quoted review of research by Philip Jacob, Changing Values in College, ${ }^{12}$ concluded that the teacher had relatively little effect upon the value orientation of students. Even the classic studies at Bennington suggested that the impact of the peer group was greater than that of individual instructors. ${ }^{13}$

\footnotetext{
${ }^{11}$ Allan O. Pfnister, A Report on the Bacca. laureate Origins of College Faculties (Washington, D.C.: Association of American Colleges, 1961).

${ }^{12}$ Philip E. Jacob, Changing Values in College (New York: Harper, 1957). $147 \mathrm{p}$.

18 Theodore M. Newcomb, Personality and Social Change (New York: Dryden, 1943).
}

On the other hand, Eddy's book takes a more positive view. ${ }^{14}$ Research on teaching methods at the University of Michigan suggests that different types of teachers and teaching are appropriate to different subject matters and students. Some students flourish under a non-directive approach, while other students become exceedingly uncomfortable and find the unstructured approach threatening. The style of teaching also seems to vary considerably from discipline to discipline.

The amount of research on the nature of teaching at the college level has been relatively limited in recent years. McKeachie's review of this research in The American College lists a great number of studies, but still presents a rather inconclusive summary. ${ }^{15}$ A great deal more research is needed. Perhaps a clearer taxonomy of teaching procedures will have to be worked out before research can be designed which will provide significant guidance to the practicing teacher.

\section{Courses on College Teaching}

A fifth issue relates to the matter of instruction in the art and science of teaching. For the future teacher, the graduate school contributes significantly to one aspect of teaching, i.e., the development of competence in a discipline. In the area of communication, however, it appears that relatively little has been done. All major graduate schools employ a large corps of graduate assistants and teaching fellows. A study underway at the university of Michigan indicates, however, that there is a wide variety of

\footnotetext{
$14 \mathrm{E}$. E. Eddy, The College Infiuence on Student Character (Washington, D.C.: American Council on Education, 1959).

${ }^{15}$ Wilbert J. McKeachie, "Procedures and Techniques of Teaching: A Survey of Experimental Studies," The American College (New York: John Wiley, 1962) p. 312-364.
} 
practices regarding specific assistance to the teaching fellows. ${ }^{16}$

A limited number of universities have developed courses in college teaching. The Harvard Faculty Committee on Teaching as a Career has over the years offered to graduate students at Radcliffe and Harvard an extracurricular course in college teaching. The course was started in 1947 and was last held in 1958 by Radcliffe. It has now been revised and leading faculty members and administrators of Harvard and Radcliffe participate in some nine sessions.

The University of Michigan provides a credit course in college teaching for graduate students. Its enrollment has gradually increased over the years, and it now attracts students from a variety of disciplines throughout the University. It still enrolls only a fraction of the graduate population, however.

The University of Michigan has also recently proposed the establishment of a Center on University Teaching. This Center would include a program of research in teaching at the college level, with special attention to the employment of various new technological devices such as teaching machines and programmed learning.

Such courses on college teaching, offered in reputable universities, represent a continuing interest in the systematic study of the science and art of teaching. However, they inevitably face considerable resistance among college faculties, which may be largely because of a failure to define more clearly the nature of the teaching process. If teaching could be viewed in the tripartite way suggested in an earlier section above, it should be seen that the question is not one of methodology versus content; it is

\footnotetext{
${ }^{10}$ Marion Rucker, "A Study of the Effectiveness of the Teaching Fellow Programs in Selected Departments of the College of Literature, Science and the Arts at the University of Michigan." (Research Underway.)
}

rather a matter of providing a systematic approach to both.

\section{Research and Teaching}

A sixth issue concerns the relationship between research and teaching. Although research may be equated with publishing, publishing may hardly be equated with good teaching. In publishing the findings of his research, the faculty member is addressing his peers and requiring their evaluation. Teaching vis-à-vis the indispensible student implies communication with one who is less than equal. The research publication and the teaching process are addressed to different audiences.

On the other hand, if research is likened to a continuous inquiry into the discipline-the making of subject matter -the teacher fails to do research at his peril. He stops growing. A good teacher must always be mastering his subject matter; he must always be looking for the relationship between one discipline and another.

If we ask whether a faculty member should publish-and here we are referring to faculty member in the broad sense rather than to the faculty member as teacher only-it may be argued that the faculty member ought periodically to come before his peers as well as before his students. The degree of emphasis on publication should vary with institutions. It is possible that the demands to publish can come into conflict with the demands to teach; the two operations are not identical. Teaching load and institutional circumstances will influence the degree to which a given faculty member can do both.

\section{Teaching as a Profession}

A seventh issue has to do with whether college teaching is, properly speaking, a profession. At an earlier point above it was suggested that college teaching was being transformed into a profession. One 
may rightly question whether college teaching is indeed one profession; perhaps it is more properly a group of professions.

Recent studies of the academic man suggest that the orientation of the faculty man is primarily to his discipline rather than to some generalized conception of "college teacher." He views himself and is viewed by his colleagues in terms of his standing as a historian, mathematician, or biologist. It is even difficult in some institutions to develop a strong governing body of faculty; the basic decisions are made at the departmental level. Is there any chance that the orientation will change? There are few who think that it will; departmental lines are becoming stronger rather than weaker. ${ }^{17}$

${ }^{17}$ Cf. Paul Lazarsfeld and Wagner Thielens, The Academic Mind (Glencoe, Illinois: the
In summary, what is the best preparation for college teachers? The answer to such a question must come, it seems to me, out of a thorough appreciation of the diverse character of American higher education. It will involve also a clear definition of the nature of teaching; a distinction between teaching and the other roles variously devolving upon faculty members; an understanding of the manner in which college teachers are recruited; a clearer understanding of the impact of the teacher on the student; an appreciation of teaching as both an art and a science; and a clearer perception of the sense in which college teaching is or can be $a$ profession.

Free Press, 1958) and Theodore Caplow and Reece J. McGee, The Academic Marketplace (New York: Basic Books, 1958).

\section{The Meaning of the Ph.D. Degree}

It is doubtless appropriate to say that the Ph.D. degree is a professional degree in the sense that it trains an individual for the profession of scholarship, but, from the point of view presented here, it is quite inappropriate to consider it a professional degree in the sense that it can be adapted to every profession which an individual may follow after leaving the university.

Many other conflicting forces exist, and doubtless will continue to be important. Some are based on the idea that the degree is primarily an honor to be awarded simply as a matter of justice to all individuals who put forth a certain amount of effort. Here the common notion is that anyone who works for approximately three years in an intellectual endeavor should automatically qualify for the degree. Similarly, some contend that students in every field of endeavor, whether there is a possibility of contributing to fundamental knowledge or not, should become eligible for doctoral degrees. Pressures are great, and some distinguished universities have capitulated. As a result, there is serious danger that the meaning of the Doctor's degree may be lost.

Another factor of importance can be described by calling it a negative pressure. This comes from the increasing demands that university faculties carry on a great variety of activities that have little or nothing to do with teaching a subject or performing research. These range all the way from student activities including counseling and guidance of undergraduates to participation in public affairs and service as consultants for industry and the government. Such demands are often in direct conflict with graduate work, since the net effect of these distractions is to reduce the concern which the faculty has for the Ph.D. program. The graduate school and its executive officer, the graduate dean, are expected to maintain the essential quality of the degree. Unfortunately, the graduate school is frequently a very loose and informal organization, and the graduate dean almost devoid of effective means of achieving this objective. Much will depend in the future on the organization of universities and the extent to which graduate work develops the strength to maintain an adequate amount of independence.-HENRY E. BENT, "THE Meaning of the Ph.D. Degree," The Journal of Higher Education 33: 16; January 1962. 